\title{
PEMANFAATAN TANAMAN HERBAL SEBAGAI SEDIAAN JAMU TRADISIONAL UNTUK PENAMBAH IMUNITAS TUBUH DI MASA PANDEMI COVID-19
}

\author{
Ana Amalia
}

\author{
STIKes Karya Putra Bangsa
}

Email Korespondensi: ana.amalia300394@gmail.com

\section{ABSTRAK}

Kasus Covid-19 semakin hari semakin bertambah, sehingga perlu adanya cara untuk memutus rantai penyebaran / transmisi dan melindungi masyarakat dari infeksi virus tersebut. Upaya yang dapat dilakukan untuk memutus rantai penyebaran yaitu dengan cara 3M (Memakai masker, Menjaga jarak, dan Mencuci Tangan). Upaya lain yang harus dilaksanakan yaitu dengan cara meningkatkan imunitas tubuh, agar virus yang menginfeksi tubuh dapat langsung dilawan oleh sistem imunitas tubuh, sehingga dapat mengurangi proses infeksi. Salah satu cara peningkatan imunitas tubuh dengan cara mengonsumsi obat tradisional (seperti ramuan herbal, jamu, ekstrak tanaman dll). Berdasarkan hasil analisa situasi, masyarakat desa ngranti belum mengetahui jenis, manfaat dan cara pembuatan dari tanaman herbal yang dapat digunakan sebagai minuman jamu untuk meningkatkan sistem kekebalan tubuh. Desain kegiatan ini menggunakan rancangan pre-eksperimental dengan rancangan pre test - post test design yaitu dengan melakukan intervensi berupa edukasi menggunakan leaflet. Edukasi yang dilakukan berisi jenis, manfaat dan cara pembuatan jamu dari tanaman herbal. Hasil pengabdian masyarakat ini menunjukkan rata-rata nilai pre test 6,1 dan rata-rata nilai post tes 7,6 , analisa spss menunjukkan terdapat peningkatan pengetahuan yang signifikan dengan nilai $p$ value 0,002 .

Kata Kunci: Covid-19, Jamu, Imunitas

\begin{abstract}
Covid-19 cases are increasing day by day, so there is a need for a way to break the chain of transmission / transmission and protect the public from infection with the virus. Efforts that can be made to break the chain of spread are by means of $3 \mathrm{M}$ (wearing masks, maintaining distance, and washing hands). Another effort that must be carried out is by increasing the body's immunity, so that viruses that infect the body can be directly resisted by the body's immune system, so as to reduce the infection process. One way to increase the body's immunity is by consuming traditional medicines (such as herbal ingredients, herbs, plant extracts, etc.). Based on the results of the situation analysis, the villagers of Ngranti do not yet know the types, benefits and methods of making herbal plants that can be used as herbal drinks to boost the immune system. The design of this activity uses a pre-experimental design with a pre-test-post-test design, namely by conducting an intervention in the form of education using
\end{abstract}


leaflets. The education carried out contained the types, benefits and methods of making herbal medicine from herbal plants. The results of this community service show an average pretest value of 6.1 and an average post-test value of 7.6 , the SPSS analysis shows that there is a significant increase in knowledge with a $p$ value of 0.002 .

Keywords: Covid-19, Herbal Medicine, Immunity

\section{PENDAHULUAN}

Corona Virus Disease 2019 (Covid-19) pertama kali ditemukan di Kota Wuhan, China pada akhir bulan Desember 2019 (Meilina \& Nadia, 2020). Pada waktu yang relatif singkat, virus ini telah menyebar ke hampir seluruh negara di dunia, termasuk Indonesia. Orang yang terinfeksi virus covid-19 ditandai dengan gejala flu yang disertai demam, pilek, batuk kering, sakit tenggorokan dan sakit kepala (Tirmidi \& Anwar, 2020). Covid-19 dapat menginfeksi tanpa memberikan gejala klinis, sehingga penderita tidak merasakan perubahan dalam dirinya. Beberapa gejala klinis yang dirasakan mulai dari flu biasa, batuk dan pilek. Gejala klinis yang lebih berat seperti demam tinggi, nyeri tenggorokan, nyeri otot, kehilangan indra pembau dan perasa, sesak nafas hingga menyebabkan kematian (Mahmud \& Indriyani, 2020).

Peta sebaran Covid-19 di Tulungagung per 20 Januari 2021 yang diperoleh dari Dinas Kesehatan Kabupaten Tulungangung, memaparkan jumlah kasus yang positif sebanyak 1850 dimana 76 orang diisolasi, 79 orang dikarantina, 212 orang dirawat, 1438 orang sembuh dan 45 orang meninggal. Kasus Covid-19 semakin hari semakin bertambah, sehingga perlu adanya cara untuk memutus rantai penyebaran / transmisi dan melindungi masyarakat dari infeksi virus tersebut (Fathoni, 2020). Upaya yang dapat dilakukan untuk memutus rantai penyebaran yaitu dengan cara 3M (Memakai masker, Menjaga jarak, dan Mencuci Tangan). Upaya lain yang harus dilaksanakan yaitu dengan cara meningkatkan imunitas tubuh, agar virus yang menginfeksi tubuh dapat langsung dilawan oleh sistem imunitas tubuh, sehingga proses infeksi selanjutnya tidak akan terjadi. Peningkatan imunitas tubuh dapat dilakukan dengan penerapan pola hidup yang sehat seperti mengonsumsi makanan yang bergizi seimbang, olahraga teratur dan dapat ditambah dengan mengonsumsi suplemen yang dapat meningkatkan sistem imun tubuh baik itu berupa obat kimia (seperti vitamin) ataupun dari obat tradisional (seperti ramuan herbal, jamu, ekstrak tanaman dll) (Imam Azizuddin, 2021).

Menurut Aliwa \& Suhartatik, 2020, peneliti Balai Besar Litbang Tanaman Obat dan Obat Tradisional (B2P2TOOT) Tumbuhan obat yang bisa digunakan untuk kebugaran atau immunumodulator (peningkat system imun tubuh) adalah kunyit (Curcuma longa), jambu biji (Psidium guajava), sirih (Piper betlel L), jahe (Zingiber officinale Roscoe), kumis kucing (Orthosiphan aristatus (Bl.) Miq), sirsak (Annona muricata L), papaya (Carica papaya), rumput merah atau alang-alang (Imperata cykindrica (L.) Raeusch) serta buah noni atau mengkudu (Morinda citrifolia L.).

Masyarakat desa ngranti di masa pandemi ini sudah menerapkan protokol kesehatan yang dianjurkan oleh pemerintah, namun masih banyak masyarakat yang belum mengetahui pemanfaatan tanaman herbal yang dapat bermanfaat untuk meningkatkan sistem imunitas tubuh. Berdasarkan 
analisa situasi di atas, kami berinisiatif untuk memberikan edukasi terkait pemanfaatan tanaman herbal sebagai sediaan jamu tradisional untuk penambah imunitas tubuh di masa pandemi covid-19. Diharapkan edukasi ini dapat meningkatkan pengetahuan masyarakat terkait manfaat penggunaan tanaman herbal dan dapat diterapkan sebagai salah satu minuman yang dapat dikonsumsi untuk meningkatkan daya tahan tubuh.

\section{MASALAH}

Masyarakat desa ngranti belum mengetahui jenis/ragam tanaman herbal yang dapat digunakan sebagai minuman jamu untuk meningkatkan sistem imun, selain itu masyarakat belum mengetahui manfaat dari tanaman herbal tersebut serta bagaimana cara pembuatan beserta takarannya dalam pembuatan jamu dari tanaman herbal.

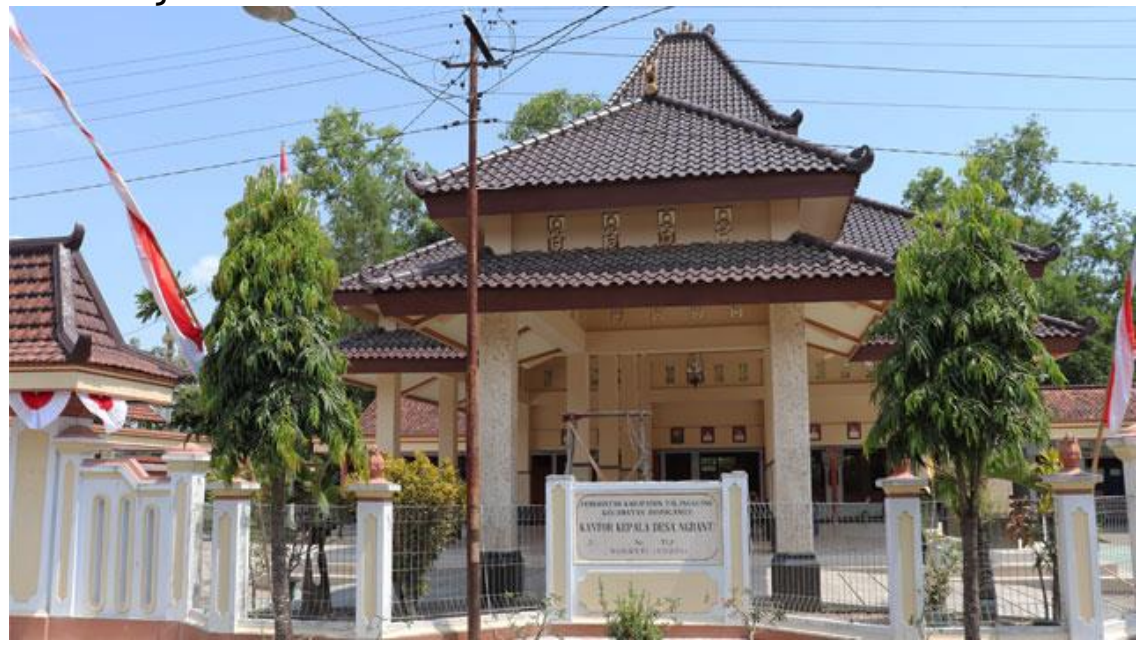

Gambar 1. Peta Lokasi Kegiatan PKM

\section{METODE}

a. Tujuan Persiapan

Tahap persiapan dari kegiatan ini adalah pembuatan leaflet, kuesioner serta alat dan bahan untuk membuat jamu. Pembuatan leaflet dan kuesioner dimulai pada tanggal 8Januari 2021, dan pada tanggal 18 Februari 2021 kegiatan PKM dilaksanakan.

b. Tahap Pelaksanaan

i. Pengajuan Ijin

Pelaksanaan kegiatan ini melalui ijin ketua RT 01 Desa Ngranti, yang kemudian memberikan arahan untuk berkumpul di rumah kader dalam melaksanakan kegiatan PKM.

ii. Proses pelaksanaan

a) Pengukuran tingkat pengetahuan responden menggunakan metode pre-eksperimental dengan rancangan pre test - post test design yaitu dengan melakukan intervensi menggunakan leaflet. Sebelum dilakukan penyuluhan, dilakukan pengukuran pengetahuan terlebih dahulu menggunakan kuesioner pre-test, kemudian dilakukan pengukuran pengetahuan lagi berupa post-test setelah dilakukan penyuluhan menggunakan leaflet, sehingga dapat dilihat perbedaan pengetahuan sebelum dan sesudah penyuluhan. 


\section{HASIL DAN PEMBAHASAN}

Kegiatan pengabdian masyarakat ini dimulai dari pengumpulan materi dan informasi tentang Covid-19 secara komprehensif, artinya dilakukan pencarian mulai dari pengertian covid-19, penyebab, gejala, penangangan, sampai dengan upaya pencegahannya. Dari informasi ini kemudian dibuat inti sari yang mana akan dijadikan bahan materi untuk pembuatan leaflet terkait covid dan penggunaan bahan jamu untuk meningkatkan imunitas tubuh.

Jamu adalah minumam herbal tradisional khas Indonesia yang masih ada samapai zaman obat modern sekarang. Bahan-bahan jamu berasal dari tumbuh-tumbuhan yang langsung diperoleh dari alam sehingga mudah didapatkan dan jamu tidak mengandung kimia sintetik sehingga efek samping yang ditimbulkan tidak terlalu besar (Kusumo et al., 2020). Kegiatan pelatihan pembuatan olahan jamu berbahan dasar rempah ini diharapkan dapat bermanfaat untuk sehatan tubuh, terutama untuk menjaga dan meningkatkan imunitas tubuh (Mahmud \& Indriyani, 2020). Berikut adalah tabel yang berisi bahan - bahan dari jami beserta manfaatnya :

Tabel 1. Kandungan dan Manfaat dari Bahan-Bahan Jamu

\begin{tabular}{|c|c|c|}
\hline Nama Bahan & Kandungan & Manfaat \\
\hline $\begin{array}{l}\text { Jahe (Zingiber } \\
\text { Officinale) }\end{array}$ & $\begin{array}{l}\text { Gingerol, Beta-Caroten, } \\
\text { Asam Cafeic,Curcumin, } \\
\text { Salicilat }\end{array}$ & $\begin{array}{l}\text { Mengandung senyawa kimia } \\
\text { aktif yang bersifat anti } \\
\text { inflamasi dan antioksidan }\end{array}$ \\
\hline $\begin{array}{l}\text { Kunyit (Curcuma } \\
\text { Longa L.) }\end{array}$ & Curcumin & $\begin{array}{l}\text { Mempermudah proses } \\
\text { pencernaan, memperbaiki } \\
\text { perjalanan usu, antioksidan, } \\
\text { antiinflamasi, antibakteri, } \\
\text { antivirus, yang berfungsi } \\
\text { meningkatkan imunitas tubuh }\end{array}$ \\
\hline $\begin{array}{l}\text { Temulawak } \\
\text { (Curcuma } \\
\text { Xanthorriza } \\
\text { Roxb) }\end{array}$ & $\begin{array}{l}\text { Curcumin, Flavonoid, } \\
\text { Minyak Atsiri }\end{array}$ & $\begin{array}{l}\text { Membantu proses metabolisme, } \\
\text { menyembuhkan radang dan } \\
\text { mengharumkan }\end{array}$ \\
\hline
\end{tabular}

Sumber: (Kusumo et al., 2020) 


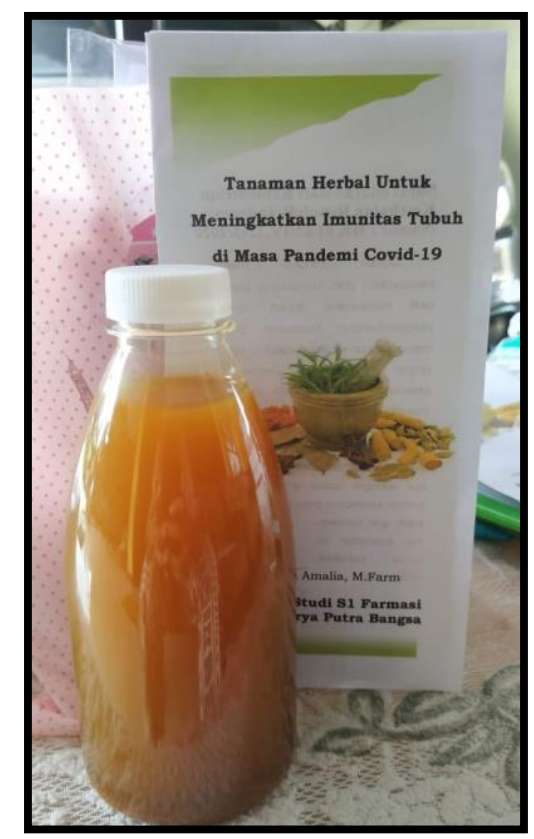

Gambar 2. Produk Jamu penambah imunitas tubuh dan leaflet

Selain bahan-bahan utama yang terdapat pada tabel 1, kita juga menambahkan bahan lain seperti gula aren untuk menambah rasa manis pada jamu, dan jeruk nipis untuk menambah sedikit rasa asam, kayu manis dan serai agar jamu terasa harum, serta garam untuk menetralisir rasa.

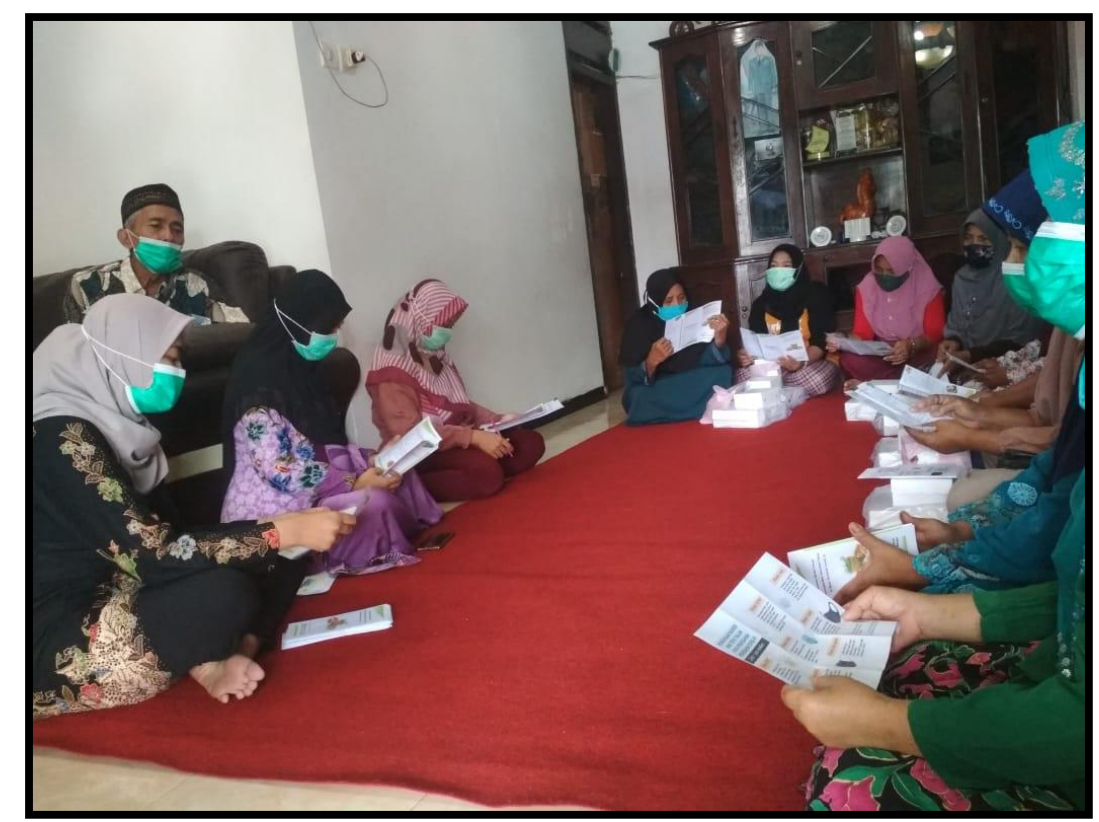

Gambar 3. Kegiatan Pemaparan Materi

Kegiatan selanjutnya yaitu pemberian informasi terkait Covid-19 dan manfaat tanaman herbal sebagai penambah daya tahan tubuh menggunakan media leaflet. Pengetahuan responden diukur menggunakan kuesioner. Hasil pengukuran pengetahuan responden terkait Covid-19 dan manfaat tanaman herbal sebagai penambah daya tahan tubuh dapat dilihat pada tabel 2 . 
Tabel 2. Pengetahuan Responden Sebelum (Pre-Test) \& Sesudah (PostTest) Diberikan Leaflet

\begin{tabular}{ccc}
\hline \multirow{2}{*}{ Tingkat Pengetahuan } & Pre-Test & Post-Test \\
\cline { 2 - 3 } & $\mathrm{n}=15(\%)$ & $\mathrm{n}=15(\%)$ \\
\hline Baik & $2(13,3)$ & $11(73,3)$ \\
Cukup & $13(86,7)$ & $4(26,7)$ \\
Kurang & 0 & 0 \\
\hline
\end{tabular}

Hasil pengukuran pengetahuan dari 15 responden menunjukkan bahwa responden memiliki tingkat pengetahuan "CUKUP" sebesar $86,7 \%$ saat pre test dan tingkat pengetahuan "BAIK" sebesar $73,3 \%$ saat post test.

Hasil pengukuran tingkat pengetahuan responden saat pre test dan post test diujikan menggunakan uji wilcoxon untuk mengetahui apakah ada pengaruh terhadap pemberian leaflet terhadap tingkat pengetahuan responden. Hasil analisa tersebut dapat dilihat pada tabel 3 .

Tabel 3. Pengaruh Pemberian Leaflet Terhadap Tingkat Pengetahuan Responden

\begin{tabular}{lcccc}
\hline $\begin{array}{l}\text { Pre }- \text { Post } \\
\text { Test }\end{array}$ & $\mathrm{n}$ & $\begin{array}{c}\text { Nilai } \\
\text { Rata-Rata }\end{array}$ & Jumlah & $\begin{array}{c}p^{-} \\
\text {Value }\end{array}$ \\
\hline $\begin{array}{l}\text { Nilai } \\
\text { negative }\end{array}$ & 0 & & & \\
$\begin{array}{l}\text { Nilai positif } \\
\begin{array}{l}\text { Nilai yang } \\
\text { sama }\end{array}\end{array}$ & 12 & 6,5 & 78 & 0,002 \\
\hline
\end{tabular}

Pada uji Wilcoxon terdapat "nilai negatif", "nilai positif", dan "nilai yang sama". Nilai negatif atau selisih negatif antara nilai pengetahuan Pre-Test dan Post-Test memiliki arti penurunan nilai pengetahuan. Pada penelitian ini tidak terdapat penurunan nilai pengetahuan. Nilai positif atau selisih positif antara nilai pengetahuan Pre-Test dan Post-Test memiliki arti terdapat meningkatan nilai pengetahuan. Hasil analisa menunjukkan ini terdapat 12 responden yang memiliki peningkatan nilai pengetahuan dengan nilai rata-rata 6,5 dan jumlah nilai keseluruhan 78. Nilai yang sama memiliki arti adanya kesamaan nilai antara nilai pengetahuan Pre-Test dan Post-Test. Pada analisa ini terdapat 3 responden yang memiliki nilai Pre-Test dan Post-Test sama. Hasil analisa menunjukkan nilai $p$-value 0,002 yang berarti ada pengaruh tingkat pengetahuan terhadap pemberian leaflet pada responden. Leaflet secara signifikan meningkatkan pengetahuan pasien. Peningkatan pengetahuan pasien dapat meningkatkan kesadaran pasien tentang penyakit dan risiko komplikasi, sehingga pasien menjadi patuh dan mengontrol tekanan darah pasien (Dewanti \& Supardi, 2015; Kansil \& Regar, 2019). 


\section{KESIMPULAN}

Pada pengabdian masyarakat ini terdapat pengaruh yang signifikan dari pemberian leaflet terhadap peningkatan pengetahuan responden dengan nilai $p$-value 0,002 .

\section{DAFTAR PUSTAKA}

Aliwa, \& Suhartatik. (2020). Pembuatan Produk Jamu Tradisional (SINOM) Sebagai Penunjang Perekonomian Masa Pandemi Covid 19 di Desa Petunjungan Kecamatan Paiton Kabupaten Probolinggo.

Dewanti, S. W., Andrajati, R., \& Supardi, S. (2015). Pengaruh Konseling dan Leaflet terhadap Efikasi Diri , Kepatuhan Minum Obat, dan Tekanan Darah Pasien Hipertensi di Dua Puskesmas Kota Depok. Jurnal Kefarmasian Indonesia.

Fathoni, M. N. (2020). Edukasi Tentang Covid-19 Serta Pemanfaatan Tanaman Herbal Pada Pedagang Jamu Keliling di Desa Tanjungsari. Jurnal Layanan Masyarakat.

Imam Azizuddin. (2021). Jamu tradisional peningkat imunitas di masa pandemi. Journal of Reasearch on Community Engagement.

Kansil, J. F., Katuuk, M. E., \& Regar, M. J. (2019). Pengaruh Pemberian Edukasi dengan Metode Focus Group Discussion Terhadap Kepatuhan Minum Obat Penderita Hipertensi. E-Journal Keperawatan, 1-8.

Kusumo, A. R., Wiyoga, F. Y., Perdana, H. P., Khairunnisa, I., Suhandi, R. I., \& Prastika, S. S. (2020). Jamu Tradisional Indonesia: Tingkatkan Imunitas Tubuh Secara Alami Selama Pandemi. Jurnal Layanan Masyarakat.

Mahmud, M., \& Indriyani, S. (2020). Inovasi Olahan Jamu Berbahan Rempah Sebagai Upaya Mendorong Pendapatan Rumah Tangga Di Masa PAndemi. Jurnal Sibermas (Sinergi Pemberdayaan Masyarakat).

Meilina, R., Dewi, R., \& Nadia, P. (2020). Sosialisasi Pemanfaatan Tanaman Obat Keluarga (TOGA) Untuk Meningkatkan Imun Tubuh di Masa Pandemi Covid19. Jurnal Pengabdian Masyarakat (Kesehatan).

Tirmidi, \& Anwar, F. (2020). Peracikan Bahan Alam (Berupa Rempah-Rempah) Dalam BEntuk Minumam Tradisional (JAMU) untuk Meningkatkan Imun Tubuh Dalam Pencegahan Covid-19 di Desa Randujalak Kecamatan Besuk. 